\title{
Isolation and selection of purple non-sulfur bacteria for phosphate removal in rearing water from shrimp cultivation
}

\author{
Patama Bunruk $^{1}$, Duangporn Kantachote ${ }^{2 *}$, Ampaitip Sukhoom ${ }^{3}$ \\ 1, 2, 3 Department of Microbiology, Prince of Songkla University, Hat Yai, Thailand
}

\author{
Index Terms \\ Phosphate Removal \\ Purple Non-Sulfur Bacteria \\ Rearing Water \\ Shrimp Cultivation
}

Received: 14 January 2017

Accepted: 19 January 2017

Published: 30 June 2017

\begin{abstract}
Therefore, this study aimed to isolate and screen PNSB from shrimp ponds with their ability to reduce phosphate in water from shrimp cultivation. A total of 83 PNSB strains were isolated from water and sediment samples collected from various 15 shrimp ponds located in Phang-nga and Songkhla provinces. For primary screening, there were 42 strains $(51 \%)$ that grew well $\left(\mathrm{OD}_{660}>1.0\right)$ in glutamateacetate broth supplemented with $1.5 \%(\mathrm{w} / \mathrm{v}) \mathrm{NaCl}$, under conditions of microaerobic-light and aerobicdark. However, in secondary screening, only two strains (W12 and W48) could grow in sterile rearing water collected from shrimp ponds. They were selected for tertiary screening to investigate their ability to remove phosphate in sterile rearing water under both incubating conditions. Both PNSB strains produced no significant differences for phosphate removal efficiency ( $>50 \%$ ) with the exception under microaerobic-light conditions as strain W12 roughly reduced $46 \%$ phosphate. Of these, 2 strains could be used as inoculants to remove phosphate from rearing water in shrimp ponds. One of the key environmental concerns about shrimp cultivation is the discharge of rearing water with high levels of nutrients, especially phosphate, into waterways, resulting in eutrophication. To solve this problem, biological treatment is well-recognized, and the use of purple non-sulfur bacteria (PNSB) is one of the attractive alternative choices because of their high removal efficiency in wastewater treatment with various metabolic growth conditions.
\end{abstract}

(C) 2017 The Author(s). Published by TAF Publishing.

\section{INTRODUCTION}

Over the past 40 years, shrimp has become the most-traded product due to higher-value product, although shrimp cultivation is faced with many serious problems. Shrimp ponds are mainly located in the Asia-Pacific region, including Thailand, China and Viet Nam, which are the major global exporting countries. A total world production of shrimp product was over 3 million tonnes in 2008 [1]. However, occurring of shrimp diseases in 2012 caused a decline of exports in some countries. Recent reports state that global shrimp production has been increased to 3.5 million tonnes with prediction to continue growing in the next decade [2].

It has long been known that shrimp cultivation is one of the most important aquaculture productions due to giving high income and employment. However, it is often responsible for severe economic and environmental problems. Several studies have reported the impacts of shrimp cultivation on ecosystems such as $[3,4,5,6,7,8]$. One of the major environmental problems from shrimp cultivation is the discharge of large quantities of rearing water without any treatments into waterways. Since there are $84 \%$ of phosphorus and $71 \%$ of total nitrogen from uneaten feeds, fertilizers inputs and faeces remaining in rearing water [9, 10]; therefore, high levels of nutrients, especially phosphate can lead to severe eutrophication problems $[11,12,10]$.

Moreover, rearing water discharge from farms causes an adverse impact on shrimp production since it is able to contaminate the water supplies used by other farms [13]. To solve these problems, the rearing shrimp water must be treated before releasing into waterways in order to remove (or reduce) these nutrients including phos-

* Corresponding author: Duangporn Kantachote

†Email: duangporn.k@psu.ac.th 
phate. One of the methods of treating wastewater is the use of photosynthetic bacteria $[14,15,16]$. A number of previous studies used purple non-sulfur bacteria (PNSB), a type of phototrophic bacteria to treat industrial and domestic wastewaters, and it was confirmed that they are highly effective in reduction of organic compounds in various wastewaters $[17,14]$.

In addition, they are capable of taking up phosphate into their cells and accumulating in the form of polyphosphate (Poly-P) granule for energy source. Thus, they have been considered as one of polyphosphate-accumulating organisms $[15,16,18]$. Nevertheless, there are a few researches focusing on using PNSB for treatment of rearing shrimp water from shrimp cultivation. Hence, objectives of this study were to isolate and select PNSB from shrimp water and sediment, and to evaluate the efficiency of phosphate removal in water from shrimp cultivation by using selected PNSB strains.

\section{LITERATURE REVIEW}

Shrimp cultivation has developed from traditional, small businesses into global industries which offer high employment opportunities in many countries including Thailand. Nowadays, there is a variety of different types of shrimp products such as raw, cooked, canned, pickled, and breaded found in global markets $[1,2,5]$. To increase carrying capacity of shrimp pond, fertilizers and mineral nutrients are pre-used to activate the growth of the phytoplankton for forming food chain. During cultivation, shrimp needs to be fed four to five times daily and more than $70 \%$ of them become waste $[9,7]$. Along with uneaten feeds, faeces and phytoplankton remaining in rearing water likewise increase level of nutrients $[3,9,5,7]$. Thus, discharge of rearing water from shrimp ponds can dramatically lead to the eutrophication wherever they are located. Eutrophication is the state of waterways which exceed in the nutrients including nitrate, organic compounds and phosphate which is a limiting factor for causing eutrophication $[4,19$, 5 , 7]. This problem causes many adverse effects on aquatic ecosystem such as increasing of the macrophyte growth, the phytoplankton blooms, the turbid state, but decreasing of oxygen at night time with finally decreasing of biodiversity $[11,5,7]$. Purple Non-Sulfur Bacteria (PNSB) is a type of phototrophic Gram-negative bacteria that naturally inhabit in fresh water, marine water, sediment and wastewater. These PNSB are capable of various metabolic growth modes (photoorganotroph under anaerobic and microae- robic-light conditions, and chemoorganotroph under aerobic-dark conditions) $[15,17,14]$. Several previous studies have selected PNSB to treat industrial and domestic wastewaters, and results showed that they have great efficiency to remove organic compounds from wastewaters $[15,17,14,16]$. Besides the high efficiency in wastewater treatment, some PNSB have ability to detoxify mercury in shrimp pond by volatilization process [20]. Moreover, PNSB have high protein in their biomass which can be used as Single Cell Protein (SCP) for animal feed [17, 14]. Recently, PNSB have been investigated for their ability to control shrimp pathogens (vibrios) and their use as probiotics for shrimp cultivation and results found that PNSB have great potential to control vibrios for sustainable shrimp cultivation [21]. According to above information, there is not much research work to use PNSB for removal of phosphate from rearing shrimp water. Hence, this research aimed to reduce phosphate level in shrimp ponds by PNSB for sustainable shrimp cultivation as the use of environment-friendly tool.

\section{MATERIAL AND METHODS}

\section{A. Collecting of Water and Sediment Samples}

With the aim to use PNSB for treating rearing water in shrimp cultivation, both sediment and water samples were collected from shrimp ponds that are located in Phang-nga and Songkhla provinces, Thailand. To obtain the representative samples, both types of sample were sampling for a total of 13 subsamples in each pond. Roughly amount of $100 \mathrm{~g}$ of sediment was collected at a $10 \mathrm{~cm}$ depth and a $100 \mathrm{~mL}$ of water at $50 \mathrm{~cm}$ depth from the surface water. All samples were kept in an ice box during transportation to a laboratory. All samples were rapidly used to isolate PNSB and then determined parameters as follows: phosphate, pH, Electrical Conductivity (EC) and salinity.

\section{B. Isolation of Purple Non-Sulfur Bacteria from Shrimp Ponds}

Glutamate-Acetate (GA) medium added with 1.5\% $\mathrm{NaCl}(\mathrm{w} / \mathrm{v})$ was used as an isolation medium (20) as follows: 3.8 g sodium L-glutamate, 5.4 g sodium acetate,

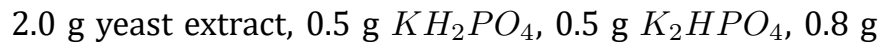
$\left(\mathrm{NH}_{4}\right)_{2} \mathrm{HPO}_{4}, 0.2 \mathrm{~g} \mathrm{MgSO}_{4} .7 \mathrm{H}_{2} \mathrm{O}, 0.053 \mathrm{~g} \mathrm{CaCl}_{2} .2 \mathrm{H}_{2} \mathrm{O}$, $0.001 \mathrm{~g}$ nicotinic acid, $0.01 \mathrm{~g}$ biotin, $0.012 \mathrm{~g} \mathrm{MnSO}_{4} .5 \mathrm{H}_{2} \mathrm{O}$, $0.025 \mathrm{~g}$ ferric citrate, $0.001 \mathrm{~g}$ thiamine hydrochloride, and $0.95 \mathrm{~g} \mathrm{CoCl}_{2} .6 \mathrm{H}_{2} \mathrm{O}$ and added up with distilled water to 
$1000 \mathrm{~mL}$ and adjusted $\mathrm{pH}$ to 6.8. For water samples, 10 $\mathrm{mL}$ of each subsample was filled into a screw cap test tube $(150 \times 15 \mathrm{~mm}: 20 \mathrm{~mL})$ containing $10 \mathrm{~mL}$ of double strength GA medium and applied with its screw cap lid [17]. Whilst, $1 \mathrm{~g}$ of each sediment subsamples was transferred into a screw cap test tube $(150 \times 15 \mathrm{~mm}: 20 \mathrm{~mL})$ containing 10 $\mathrm{mL}$ of normal strength GA medium and covered with liquid paraffin and applied with its screw cap lid.

All tubes were incubated under microaerobic-light conditions by setting with tungsten bulbs and adjusted light intensity to $3,500 \pm 200$ lux at $30^{\circ} \mathrm{C}$ for 5 -7 days. For obtaining pure PNSB strains, culture broths displaying in pink to brown shade were re-streaked on GA agar medium plates and incubated in an anaerobic jar under light condition as previously described. A light microscope was used to check their purity after Gram staining, and each pure culture was kept in $20 \%$ glycerol at $-80^{\circ} \mathrm{C}$ in a freezer.

\section{Inoculum Preparation}

Each pure culture was loaded into a screw cap test tube $(150 \times 15 \mathrm{~mm}: 20 \mathrm{~mL})$ of $18 \mathrm{~mL}$ GA containing $1.5 \%$ $\mathrm{NaCl}$ and incubated under microaerobic light conditions as previously described in the isolation step for $48 \mathrm{~h}$. After twice subcultures, each bacterial culture was adjusted to an optical density at $660 \mathrm{~nm}\left(\mathrm{OD}_{660}\right)$ of 1.0 by using a spectrophotometer. GA medium containing $1.5 \% \mathrm{NaCl}$ was used as diluents and blank.

\section{Selection of PNSB Strains with Potential of Phosphate Removal \\ Shrimp water preparation}

Water samples from shrimp ponds were selected for this study as they were rich in nutrients before were flushed out of ponds.

Rearing waters were collected from various shrimp ponds to obtain a representative sample and fully filled in a $25 \mathrm{~L}$ black plastic tank to avoid aerobic light conditions and kept under $4 \pm 2{ }^{\circ} \mathrm{C}$ in a cold room until use. Before testing, the rearing water was filtered through cheese cloth and then autoclaved to get sterile rearing shrimp water.

\section{Primary screening}

To select PNSB that could grow well in rearing water from shrimp farm, all isolated PNSB were screened in GA broth supplemented with $1.5 \% \mathrm{NaCl}$ under both microaerobic-light and aerobic-dark conditions. The PNSB strains that grew well under both incubating conditions were selected for secondary screening.

Aerobic-dark conditions (Chemoorganotroph): 1 $\mathrm{mL}$ of each inoculum was transferred into $9 \mathrm{~mL}$ GA broth containing $1.5 \% \mathrm{NaCl}$ in a screw cap test tube $(150 \times 25$ $\mathrm{mm}$ : $50 \mathrm{~mL}$ ) and incubated under dark-covered shaker at $150 \mathrm{rpm}, 30^{\circ} \mathrm{C}$ for $48 \mathrm{~h}$. Bacterial growth was measured by a spectrophotometer as previously described with using the uninoculated medium as blank and control.

Microaerobic-light conditions (Photoheterotroph): $2 \mathrm{~mL}$ of each inoculum was added to a screw cap test tube (150 x $15 \mathrm{~mm}$ : $20 \mathrm{~mL}$ ) containing $18 \mathrm{~mL}$ GA with $1.5 \%$ $\mathrm{NaCl}$ to provide no headspace and incubated under light using tungsten lamps for $48 \mathrm{~h}$. Bacterial growth was measured by a spectrophotometer as previously described.

\section{Secondary screening}

To select the potential PNSB to grow in shrimp water, selected PNSB obtained from primary screening were grown in sterile rearing shrimp water. To avoid nutrients from GA broth, each PNSB strain was centrifuged and washed twice with $0.85 \% \mathrm{NaCl}$ before setting inoculums at $\mathrm{OD}_{660}=1.0$ using $0.85 \% \mathrm{NaCl}$. Tested PNSB were incubated under both aerobic-dark and microaerobic-light conditions as previously described for 7 days. Any PNSB strains that produced maximal growth under both incubation conditions were chosen to exam in their phosphate removal capacity.

\section{Tertiary screening}

To select the potential PNSB with ability to reduce phosphate, the PNSB strains were cultured as described in secondary screening. Before analysis, all samples were centrifuged at $6,000 \mathrm{rpm}$ for $15 \mathrm{~min}$ to obtain culture supernatants for phosphate and $\mathrm{pH}$ measurements at days 0 and 7.

The percentage of removal was calculated as below formula. For cell pellets, methylene blue staining was applied to determine poly-P accumulation $[15,22]$ and then analyzed with a bright field microscope.

(\%)Phosphate removal $=$ $\frac{[\text { phosphateconcentrationatday } 0]-[p h o s p h a t e c o n c e n t r a t i o n a t d a y 7]}{p h o s p h a t e c o n c e n t r a t i o n a t t d y 0} \times$ 100 


\section{E. Water and Sediment Analysis}

All samples of water and sediment collected from shrimp ponds were used to determine the following parameters: $\mathrm{pH}$ and Electrical Conductivity (EC) by a $\mathrm{pH}-$ conductivity meter (Seven Multi, Mettler Toledo, USA), phosphate by phosphate test (Merck, 1.14842.0001, APHA 4500-P C) and salinity (\%) by a salinometer.

\section{F. Statistical Analysis}

All experiments in this study were performed in triplicate. Statistical analysis using SPSS program version 11.5 (Lead Technologies, Armonk, NY, USA), one way ANOVA to analyze statistical differences at a p-value $<0.05$ and compared means were conducted by the Duncan's multiple test.

\section{RESULTS}

\section{A. Characterization of Water and Sediment from Shrimp Ponds}

Physicochemical properties of water and sediment samples collected from 15 shrimp ponds in southern Thailand, Phang-nga and Songkhla are shown in Table 1. The average phosphate contained in rearing water was $3.99 \pm$ $0.92 \mathrm{mg} / \mathrm{l}$ with a high variation. Average $\mathrm{pH}$ value of water samples was slightly alkaline (7.24 \pm 0.20$)$; however, $\mathrm{pH}$ in sediments was nearly neutral $(6.76 \pm 1.06)$ with a wide range. Values of EC measured from water and sediment were much different.

The EC value that represents the ion of nutrient contained in solution was $27.99 \pm 11.06 \mathrm{dS} / \mathrm{m}$ for the water samples, and $19.33 \pm 14.51 \mathrm{dS} / \mathrm{m}$ for the sediment samples. Average salinity in water samples was $2.2 \pm 1.1 \%$. Value is mean of three determinations and its standard deviation (SD), nd = not determined.

TABLE 1

PHYSICOCHEMICAL PROPERTY OF SAMPLES COLLECTED FROM 15 SHRIMP PONDS IN PHANG-NGA AND SONGKHLA PROVINCES, THAILAND

\begin{tabular}{ccccc}
\hline \hline & Water & & Sediment & \\
Parameters & Mean \pm SD & (Range) & Mean \pm SD & (Range) \\
\hline Phosphate $(\mathrm{mg} / \mathrm{l})$ & $3.99 \pm 0.92$ & $(<0.5-5.3)$ & nd & nd \\
pH & $7.24 \pm 0.20$ & $(6.31-7.60)$ & $6.76 \pm 1.06$ & $(3.79-8.11)$ \\
Electrical conductivity (dS/m) & $27.99 \pm 11.06$ & $(10.13-46.20)$ & $19.33 \pm 14.51$ & $(0.82-79.32)$ \\
Salinity (\%) & $2.2 \pm 1.1$ & $(1.0-4.2)$ & nd & nd \\
\hline \hline
\end{tabular}

ISSN: 2414-3103

DOI: $10.20474 /$ japs-3.2.5

\section{B. Isolation of PNSB from Shrimp Ponds}

With the use of GA medium supplemented with 1.5\% $\mathrm{NaCl}(\mathrm{w} / \mathrm{v})$, the PNSB that grew in the test tubes from both water and sediment samples were isolated to obtain single colonies and re-streaked for their purification. A total of 83 pure cultures were obtained from 15 shrimp ponds. There were 68 isolates (81.93\%) from 45 water samples (roughly 3 isolates/2 samples) and 15 isolates from 45 sediment samples (roughly 3 isolates/10 samples) as shown in Table 2.

TABLE 2

NUMBERS OF PNSB STRAINS ISOLATED FROM SHRIMP PONDS IN PHANG-NGA AND SONGKHLA PROVINCES

\begin{tabular}{ccc}
\hline \hline & Number of PNSB Isolates \\
Sample & Phang-nga (2 districts) & Songkhla (2 districts) \\
\hline Water $(\mathrm{n}=45)$ & 47 & 21 \\
Sediment $(\mathrm{n}=45)$ & 13 & 2 \\
Total $(\mathrm{n}=90)$ & 60 & 23 \\
\hline \hline $\mathrm{n}=$ number of samples &
\end{tabular}

\section{Selection of Potential PNSB for Phosphate Removal from Rearing Shrimp Water Primary screening}

A total of 83 PNSB strains isolated from both water and sediment samples collected from 15 shrimp ponds were screened by GA broth medium supplemented with $1.5 \% \mathrm{NaCl}$ under 2 incubating conditions of microaerobiclight and aerobic-dark.

Most of the PNSB isolates grew well under aerobicdark condition which showed values of OD ${ }_{660}>1.0$ for 51 isolates $(61.45 \%)$. However, there were only 42 isolates $(50.60 \%)$ that similarly presented high OD values under the light condition (Figure 1). Then, all PNSB isolates were chosen for further test on their potential growth in sterile shrimp water.

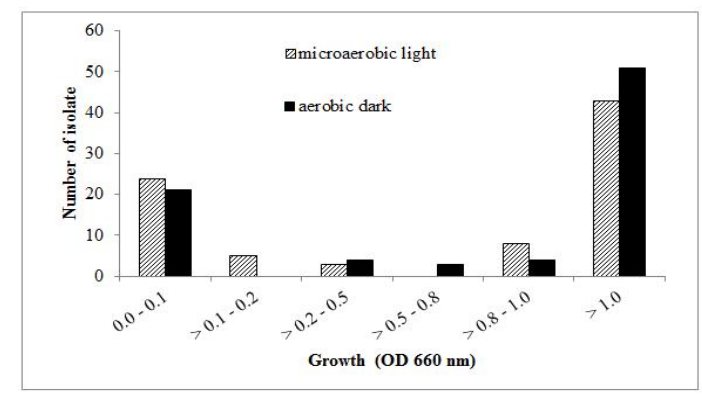

Fig. 1. Number of PNSB strains grown in GA broth containing $1.5 \% \mathrm{NaCl}$ under microaerobic-light and aerobic-dark conditions for $48 \mathrm{~h}$ 


\section{Secondary screening}

All 42 PNSB isolates obtained from primary screening were objected to test for their ability to grow in sterile rearing shrimp water. Figure 2 shows all of them presented OD $660<0.3$ in both incubating conditions as only strains W12 and W48 showed the highest growth (OD ${ }_{660} \approx 0.2$ ). Hence, both PNSB strains were further tested for their ability to remove phosphate in sterile rearing shrimp water.

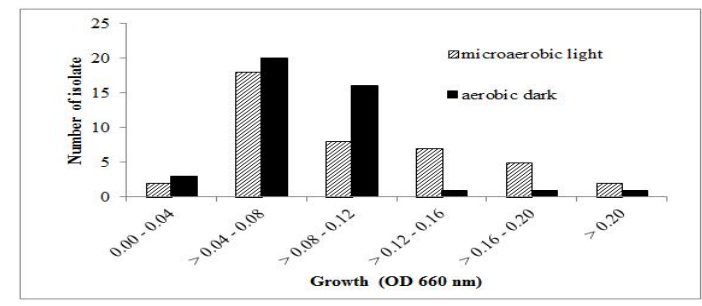

Fig. 2. Number of isolated PNSB grown in sterile rearing shrimp water under microaerobic-light and aerobic-dark conditions for 7 days

\section{Tertiary screening}

Removal of phosphate from sterile rearing shrimp water under both incubating conditions for 7 days by both selected PNSB strains (W12 and W48) is presented in Figure 3. Strain $W 12$ showed the highest percentage of phosphate removal (56.69 $\pm 0.17 \%)$ under dark condition, followed by strain W48 (55.00 $\pm 0.04 \%)$ under microaerobiclight and (52.14 $\pm 0.40 \%)$ aerobic-dark conditions although these were not significantly different ( $p>0.05$ ). In contrast, strain W12 was the least effective to remove phosphate (45.67 $\pm 1.06 \%)$ under microaerobic-light conditions. The loss of phosphate was also found in abiotic control sets (2.54 $\pm 0.06 \%$ and $3.28 \pm 0.06 \%$ under microaerobic-light and aerobic-dark conditions, respectively). In addition, $\mathrm{pH}$ value dramatically increased from 6.90 to 8.22 at the end of the treatment including in the abiotic control sets.

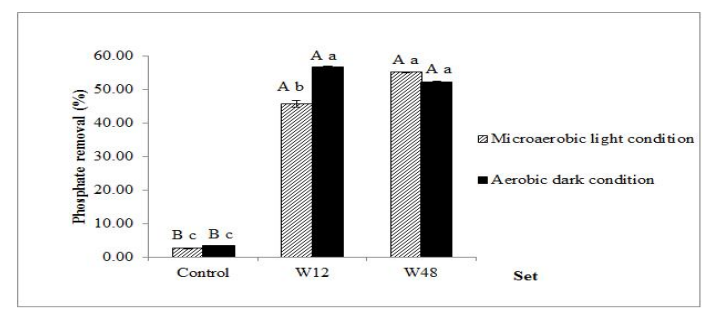

Fig. 3 . Efficiency of phosphate removal by selected PNSB strains in sterile rearing shrimp water under conditions of aerobic-dark and microaerobic-light for 7 days.

ISSN: $2414-3103$

DOI: $10.20474 /$ japs-3.2.5
The different upper case letters on each bar indicate significant differences among 3 sets (control, W12 and W48); whereas different lowercase letters in each bar indicate significant differences between 2 incubating conditions of each set $(p<0.05)$.

Control is an abiotic control as without addition of inoculants. Moreover, the cell pellets of both selected strains after treatment were objected to detect intracellular poly-P granules by staining with methylene blue. The methylene blue is specific for poly-P granules and the signal is relatively strong. Poly-P granules appeared to be pink-violet on a pale blue cell background (Figure 4).
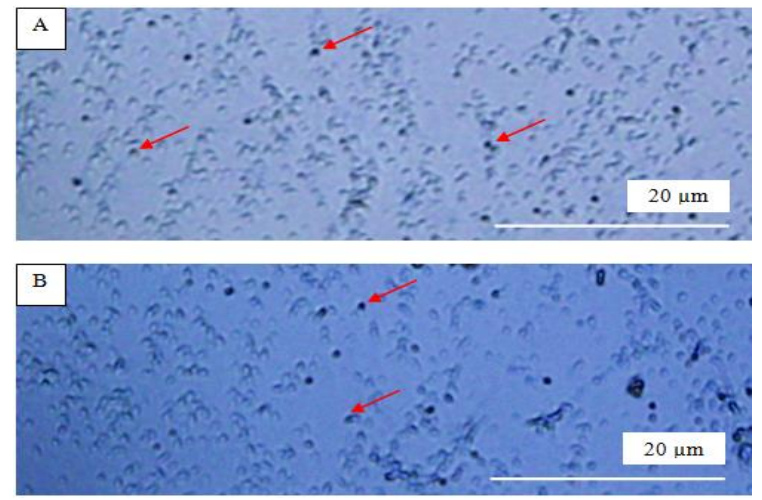

Fig. 4. Polyphosphate detection by methylene blue straining of PNSB strains (A) W12 and (B) W48. The arrows showed intercellular poly-P granules

\section{DISCUSSION}

\section{A. Physicochemical Property of Water and Sediments Col- lected from Shrimp Ponds}

Parameters measured in water from shrimp ponds such as $\mathrm{pH}$ and salinity were in ranges of standard water quality (Table 1) that were suitable for marine shrimp farming production of Thailand (TAS-7401-2009) and the recommendation for water quality in shrimp farming in the study of [8]. The $\mathrm{pH}$ values required for shrimp cultivation are in a range of $7.0-8.3$ and the salinity is between 0.05 and $3.50 \%$.

However, our measurements indicated that phosphate level was extremely higher than the standard level that should be less than $0.1 \mathrm{mg} / \mathrm{l}$ [8]. This was also higher than the exceeding-phosphate value measured in effluent water of shrimp farm in Gila Bend, AZ [19] who reported a high level of phosphate at $0.33 \mathrm{mg} / \mathrm{l}$ (ranging between 0.06 
and $0.78 \mathrm{mg} / \mathrm{l})$. These may be due to the overload of pellet feed use and fertilizer use for the first water input, the using reused-water and the remaining of high nutrients [3].

\section{B. PNSB Isolation from Shrimp Ponds}

Purple non-sulfur bacteria normally distribute in various habitats such as fresh and marine water, sediments, and wastewaters $[16,20,23]$. According to the isolation of PNSB strains from the shrimp ponds as shown in Table 2, it was indicated that most of them were isolated from water as a greater number of isolates (81.93\%). These results are in accordance with a previous study of [20] this is due to the effect of the turbidity in the water column, and some distance between sediment and water surface could block sunlight from passing through the sediment.

\section{Selection of PNSB for Phosphate Removal in Shrimp Ponds}

Our isolated PNSB strains are able to grow in rearing shrimp water although their growth abilities were not high (Fig. 2). This might be low organic matter in rearing water; however, they have the possibility to be used in shrimp ponds.

Two PNSB strains showed quite high efficiency to remove phosphate from rearing shrimp water without optimization (Fig. 3). Their removal seemed to be higher when incubated under aerobic-dark conditions than under microaerobic-light conditions. This indicates that they preferred chemoorganotroph by using organic compounds as sources of energy and carbon, and $\mathrm{O}_{2}$ as a final electron acceptor $[17,16,24]$.

Nonetheless, there is a limited report on relevant literature concerning the use of PNSB for treating phosphorus in rearing water from shrimp farm, then this study was comparable with others related to treatments by PNSB. Our PNSB cultures in sterile rearing shrimp water without optimization could remove phosphate up to $57 \%$ which was higher than a study of [21] who reported the ability of Rhodobacter sphaeroides IL106 that could reduce only $10 \%$ phosphorus from an oyster farm waste after 7 days of incubation.

However, after $24 \mathrm{~h}$ PNSB could remove roughly 88\% phosphate from industrial and domestic wastewaters under their optimal conditions and stimulation using infrared irradiation [15].
A lower efficiency to remove phosphate by our PNSB strains is due to a lower level of nutrients in rearing shrimp water compared to other wastewaters and no adjustment of the optimal conditions. Interestingly, the selected culture had a quite high capacity to remove phosphate without the exceeding growth. This was because cells were led to grow in starvation stage since there was lower nutrient in rearing shrimp water than that in enrichment GA medium, thereby they responded by reducing growth and increasing the accumulation of inorganic poly-P granules for an energy source inside the cells [25]. These results indicated that our PNSB strains could remove phosphate from environment and then continuously accumulate them in the form of poly-P [Fig. 4; 15, 16]. However, poly-P detection by staining with methylene blue could not present clear intracellular poly-P granules due to the effect of organic matter in rearing shrimp water as shown in Figure 4. After the end of the experiment, the $\mathrm{pH}$ increased from 7.0 to 8.2 roughly, which were in the optimal range for shrimp cultivation.

The increase of $\mathrm{pH}$ values in wastewater plants being likely due to the removal of soluble organic matter and the uptake of $\mathrm{CO}_{2}$ by PNSB could lead to raise up the $\mathrm{pH}$ values $[26,14]$. However, the possible reason in our study was due to the ammonification occurred during the treatment [17] by releasing of ammonium ion from organic nitrogen. In addition, previous studies demonstrated that high $\mathrm{pH}$ values of 7.5 and 8.0 could be advantage for increasing the rate of phosphorus uptake and biomass growth of polyphosphate accumulating organisms than a low $\mathrm{pH}[27,28,29]$. A high $\mathrm{pH}$ level also provides the condition for precipitation of phosphate to insoluble calcium or magnesium phosphate [26], as one of the chemical processes to reduce phosphate in natural water ways.

\section{CONCLUSION}

Our results concluded that phosphate level was dramatically higher than the standard level for discharge. Therefore, the rearing water from shrimp cultivation must be treated before discharge to avoid ecological problems.

As PNSB is normally found in rearing water and sediment of shrimp ponds, however, there are a few PNSB strains which have high efficiency of phosphate removal. Our results proved that two promising PNSB strains (W12 and W48) have a great potential to be used for reducing phosphate in shrimp cultivation since they displayed quite high ability of phosphate removal from rearing shrimp water without optimization. Therefore, their ability to reduce phosphate in non-sterile rearing shrimp water under obti- 
mization is being investigated in our current work, in order to verify an actual use in real rearing water.

\section{ACKNOWLEDGMENT}

This work was supported by Thailand Research Fund, Development and Promotion of Science and Technology Talents Project (DPST) jointly administered by the Ministry of Science and Technology, the Ministry of Education and the Institute for the Promotion of Teaching Science and Technology (IPST) and partly supported by Graduate School, Prince of Songkla University.

\section{REFERENCES}

[1] Food and Agriculture Organization, "The state of world fisheries and aquaculture 2010," 2010

[On- line]. Available: goo.gl/strwZX

[2] Food and Agriculture Organization, "The state of world fisheries and aquaculture 2016: Contribut- ing to food security and nutrition for all," 2016 [On- line]. Available: goo.gl/1s2vyK

[3] P. T. Anh, C. Kroeze, S. R. Bush and A. P. Mol, "Wa- ter pollution by intensive bracish shrimp farming in South-East Vietnam: Causes and options for con- trol," Agricultural Water Management, vol. 97, no. 6 ,

pp. 872-882, 2010.

DOI: $10.1016 /$ j.agwat.2010.01.018

[4] L. S. Herbeck, D. Unger, Y. Wu and T. C. Jennerjahn, "Effluent, nutrient and organic matter export from shrimp and fish ponds causing eutrophication in coastal and back-reef waters of NE Hainan, tropi- cal China," Continental Shelf Research, vol. 57, no. 3 ,

pp. $92-104,2013$.

DOI: $10.1016 /$ j.csr.2012.05.006

[5] H.W. Paerl, "Assessing and managing nutrienthanced eutrophication in estuarine and coastal ters: Interactive effects of human and climatic turbations," Ecological Engineering, vol. 26, no. 1, pp. 40-54, 2006.

DOI: $10.1016 /$ j.ecoleng.2005.09.006

[6] M. J. Phillips, "Shrimp culture and the environment," in Proceedings of the Seminar-Workshop on Aquacul- ture Development in Southeast Asia, Iloilo City, Philip- $\quad$ pines, 1995.

[7] Y. Thomas, C. Courties, Y. E. Helwe, A. Herbland and H. Lemonnier, "Spatial and temporal extension of eutrophication associated with shrimp farm wastewater discharges in the New Caledonia lagoon," Marine Pollution Bulletin, vol. 61, no. 7, pp. 387- 398, 2010. DOI: 10.1016/j.marpolbul.2010.07.005

[8] S. Thongrak, T. Prato, S. Chiayvareesajja and W. Kurtz, "Economic and water quality evaluation of intensive shrimp production systems in Thailand," Agricul-

tural Systems, vol. 3, no. 2-3, pp. 121-141, 1997.

DOI: $10.1016 /$ S0308-521X(96)00065-0

[9] Y. Avnimelech and G. Ritvo, "Shrimp and fish pond soils: Processes and management," Aquaculture, vol. 220, no. 1, pp. 549-567, 2003.

DOI: $10.1016 / \mathrm{S} 0044-8486(02) 00641-5$

[10] H. C. J. Godfray, J. R. Beddington, I. R. Crute, L. Haddad, D. Lawrence, J. F. Muir,... and C. Toulmin, "Food security: The challenge of feeding 9 billion people," Science, vol. 327, no. 5967, pp. 812-818, 2010.

[11] K. Somsai, T. Tondee and S. Kerdsuwan, "Effect of pile height on heat generated during rotary biodrying process for municipal solid waste (MSW)," Interna- tional Journal of Applied and Physical Sciences, vol. 1, no. 3, pp. 67-78, 2015.

DOI: $10.20469 /$ ijaps.50004-3

[12] S. Noura, K. Mohamed, A. Mohammed and B. Annick, "Extraction of residual sugars from sweet pearl millet and sweet sorghum bagasse for an eventual production of bioethanol," International Journal of Applied and Physical Sciences, vol. 1, no. 1, pp. 14-18, 2015. DOI: 10.20469/ijaps.50002

[13] A. R. Templeton, E. Routman and C. A. Phillips, "Sep- arating population structure from population his- tory: A cladistic analysis of the geographical distri- bution of mitochondrial DNA haplotypes in the tiger salamander Ambystoma tigrinum," Genetics, vol. 140, no. 2, pp. 767-782, 1995.

waper-

[14] N. Kornochalert, D. Kantachote, S. Chaiprapat and S. Techkarnjanaruk, "Bioaugmentation of latex rubber sheet wastewater treatment with stimulated indige- nous purple nonsulfur bacteria by fermented pineap-

ple extract," Electronic Journal of Biotechnol-

ogy, vol. 17, no. 4, pp. 174-182, 2014.

DOI: $10.1016 /$ j.ejbt.2014.06.003

[15] T. Hülsen, D. J. Batstone and J. Keller, "Pho- 

domes-

totrophic bacteria for nutrient recovery from

tic wastewater," Water Research, vol. 50, pp. $18-$ 26, 2014. DOI: $10.1016 /$ j.watres.2013.10.051

[16] C. M. Liang, C. H. Hung, S. C. Hsu and C. Yeh, "Pur- ple nonsulfur bacteria diversity in activated sludge and its potential phosphorusaccumulating ability under different cultivation conditions," Applied Mi- crobiology and Biotechnology, vol. 86, no. 2, pp. 709- 719, 2010. DOI: 10.1007/s00253-009-2348-2

[17] D. Kantachote, S. Torpee and K. Umsakul, "The poten- tial use of anoxygenic phototrophic bacteria for treating latex rubber sheet wastewater," Electronic Journal of Biotechnology, vol. 8, no. 3, pp. 315-323, 2005. DOI: 10.2225/vol8-issue3-fulltext-8 [18] H. Lu, G. Zhang, X. Dai, L. Schideman, Y. Zhang, B. Li and H. Wang, "A novel wastewater treat- ment and biomass cultivation system combining photosynthetic bacteria and membrane bioreactor technology," Desalination, vol. 322, pp. 176-181, 2013. DOI: $10.1016 /$ j.desal.2013.05.007

[19] D. McIntosh and K. Fitzsimmons, "Characterization of effluent from an inland, low-salinity shrimp farm: What contribution could this water make if used for irrigation," Aquacultural Engineering, vol. 27, no. 2, pp. 147-156, 2003.

DOI: $10.1016 / \mathrm{S} 0144-8609(02) 00054-7$

[20] K. Mukkata, D. Kantachote, B. Wittayaweerasak, S. Techkarnjanaruk, M. Mallavarapu and R. Naidu, "Dis- tribution of mercury in shrimp ponds and volatiliza- tion of $\mathrm{Hg}$ by isolated resistant purple nonsulfur bac- teria," Water Air and Soil Pollution, vol. 226, no. 5, pp. 148-151, 2015. DOI: 0.1007/s11270-015-2418-2

[21] S. Chumpol, D. Kantachote, P. Rattanachuay, V. Vud- dhakul, T. Nitoda and H. Kanzaki, "In vitro and in vivo selection of probiotic purple nonsulphur bac- teria with an ability to inhibit shrimp pathogens: Ac-

ute hepatopancreatic necrosis disease-causing Vibrio parahaemolyticus and other vibrios," Aqua- $\quad$ culture Research, vol. 3, no. 6, pp. 22-34, 2016. DOI: 10.1111 /are.13149

M. Hupfer, S. Gloss, P. Schmieder, P and
H. P Grossart, "Methods for detection and quantifica- tion of polyphosphate and polyphosphate accumu- lating microorganisms in aquatic sediments," Inter- national Review of Hydrobiology," vol. 93, no. 1, pp. 1-10, 2008. DOI: 10.1002/iroh.200610935

[23] T. Nunkaew, D. Kantachote, T. Nitoda and H. Kan- zaki, "Selection of salt tolerant purple nonsulfur bac- teria producing 5-aminolevulinic acid (ALA) and re- ducing methane emissions from microbial rice straw degradation," Applied Soil Ecology, vol. 86, pp. 113- 120, 2015. DOI: 10.1016/j.apsoil.2014.10.005

[24] T. Nunkaew, D. Kantachote, T. Nitoda and H. Kan- zaki, "The use of rice straw broth as an appropriate medium to isolate purple nonsulfur bacteria from paddy fields," Electronic Journal of Biotechnology, vol. 15, no. 6, pp. 1-12, 2012.

[25] D. Ault-Riché, C. D. Fraley, C. M. Tzeng and A. Korn- berg, "Novel assay reveals multiple pathways reg- ulating stress-induced accumulations of inorganic polyphosphate in Escherichia coli," Journal of Bacte- riology, vol. 180, no. 7, pp. 1841-1847, 1998.

[26] Y. Cohen and H. Kirchmann, "Increasing the $\mathrm{pH}$ of wastewater to high levels with different gases- $\mathrm{CO}_{2}$ stripping," Water, Air, and Soil Pollution, vol. 159, no. 1, pp. 265-275, 2004.

DOI: $10.1023 /$ B:WATE.0000049185.69759.b0

[27] A. Oehmen, M. T. Vives, H. Lu, Z. Yuan and J. Keller, "T-

he effect of $\mathrm{pH}$ on the competition between polyphosphate-accumulating organisms and glycogen-accumulating organisms," Water Research, vol. 39, no. 15, pp. 3727-3737, 2005.

DOI: $10.1016 /$ j.watres.2005.06.031

[28] T. Kim, M. Kang and S. K. Kim. 2015 "Measurement of thermal diffusivity of $\mathrm{V}_{2} \mathrm{O}_{5}$ thin films using nanosecond thermoreflectance technique," International Journal of Applied and Physical Sciences, vol. 1, no. 2, pp. 27-31, 2015. DOI: 10.20469/ijaps.50001-2

[29] N. Lefebvre, M. Khelifi and Y. De. Ladurantaye, "De- $\quad$ sign of a prototype press for in-field pressing of sweet sorghum and sweet pearl millet biomass," Journal of Applied and Physical Sciences, vol. 1, no. 1. pp. 29-32, 2015. DOI: $10.20474 /$ japs-1.1.5

— This article does not have any appendix. — 